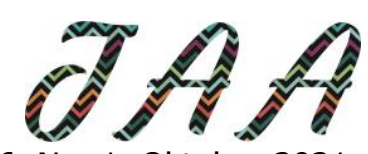

Vol. 6, No. 1, Oktober 2021

\title{
FIRM VALUE PERFORMANCE: PROFITABILITY PERSPECTIVE AND CAPITAL STRUCTURE AT STATE- OWNED BANK
}

\author{
Nengah Sukendri \\ Gde Pudja Mataram State Hindu Institute \\ sukendri1984@gmail.com \\ Ni Putu Ari Aryawati \\ Gde Pudja Mataram State Hindu Institute \\ ari_aryawati@stahn.ac.id
}

Article History:

Received: $22^{\text {nd }}$ September 2021

Revised: $15^{\text {th }}$ October 2021

Accepted: $18^{\text {th }}$ October 2021

DOI: $10.29303 /$ jaa.v6i1.110

\begin{abstract}
This study aims to determine the relationship and influence of profitability variables and capital structure on firm value toward BUMN's bank listed stated-owned enterprises 2014-2018 in Indonesia. The method of determining the sample is pooling data that examines the entire population and found as many as 4 companies using multiple linear regression with SPSS 23.0 analysis technique. Based on the results of the analysis found that profitability has a significant effect on firm value. Capital structure has no significant effect on firm value.
\end{abstract}

Keywords; Profitability; Capital Structure; Firm Value

\section{INTRODUCTION}

The condition of the company in the era of industry 4.0 and intense competition is described by the value of the company, including the need to be considered by SOEs. State-Owned Enterprises (SOE) had a very rapid development in 2004, but there was a decline due to mergers and holdings in several SOEs. The increase in profits in SOEs occurred in 2017 as many as 38 companies while the other 3 companies experienced negative growth. Restructuring is one of the efforts made by the government in the context of restructuring SOEs. This is carried out by involving State Equity Participation (PMN), an option to attract strategic investors to holding SOEs.

From a total of 118 State-Owned Enterprises, until 2017 only 20 BUMN companies were listed on the Indonesia Stock Exchange. BUMN is one source of income that can improve the national economy, so BUMN needs to pay attention to the value of the company. One way that can be done to increase the value of the company is by going public. Companies that go public in attracting investors always try to improve their performance, one aspect of which is transparency. The aspect of 
transparency can affect the assessment which can affect the demand and supply of stock prices on the stock exchange.

Business competition due to global economic conditions that continues to develop in line with technological developments and globalization creates business competition. Companies are encouraged to adapt and innovate to survive and obtain optimal profits. Business profitability is an effort to improve company performance. Company performance can be seen from the value of the company. Firm value is a benchmark for consumers and investors in perceiving the state of the company.

The value of the company can increase or decrease. In empirical studies that explain firm value is influenced by capital structure such as Riaz and Qasim (2016); Prastuti (2016); Dewi and Wirajaya (2013); and Ha and Tai (2017). In evaluating how the prospect of income will be obtained and the risks in the long term, capital structure analysis is needed. The capital structure will certainly affect the financial position in the company which indirectly has an impact on the company's performance (Fahmi, 2016:190). The company always expects an optimal capital structure which can be demonstrated by maximizing the share price of the capital structure, of course the optimal target of the expected value is not fixed and can also be influenced by company management decisions.

One of the methods used to measure capital structure is using debt to equity ratio (DER) analysis. The financial risk that occurs in the use of debt is directly proportional. This means that the higher the use of debt, the higher the financial risk in the company. DeAngelo and Stulz (2014) state that risk management is needed in banks, especially for assets in order to allow liquidity in a high position, for this reason, monitoring, diversification, hedging, and the use of derivatives are needed. debt is more secure.

Research conducted by Winarto (2015) and Sabrin et al. (2016) explained that profitability has a positive influence on firm value. This is different from the results found by Munawaroh and Priyadi (2014) and Herawati (2013) which state that profitability has a significant negative effect on firm value. Hauteas and Muslichah (2019) found that profitable companies tend to use debt funds for company operations such as expansion to encourage increased profits in the future.

Signaling theory put forward by Brigham and Houtson (2010) explains that a signal or signal is an action taken by the company to provide instructions for investors about how management views the company's prospects. This signal theory explains how companies provide signals such as what information has been done by management to realize the wishes of investors. Therefore, signaling theory is an attempt to maximize firm value. 


\section{AA}

Vol. 6, No. 1, Oktober 2021

One important aspect that affects the value of the company is the capital structure. In line with the research of Hauteas and Muslichah (2019), the capital structure has a significant effect on the value of the company, if the position of the capital structure is below the optimal point then any increase in debt will increase the value of the company and vice versa if the position of the capital structure is above the optimal point then any increase in debt will decrease the value of the company. The results of research related to the influence between capital structure and firm value were carried out by Setyowati (2011), Cuong (2014), Dewi et al. (2014), Herumingsih (2012), and Prastuti (2016) found that capital structure has a positive influence on firm value. However, found inconsistencies in the results of research conducted by Dewi and Wirajaya (2013), Priya et. al. (2015), and $\mathrm{Ha}$ and Tai (2017) who found that there was a negative effect of capital structure on firm value. This is in line with the trade off theory proposed by Myers (1984) which states that if the position of the capital structure is below the optimal point then any increase in debt will increase the value of the company and vice versa if the position of the capital structure is above the optimal point then any increase in debt debt will reduce the value of the company.

Based on the results of research that has been carried out previously and resulted in inconsistencies in the results of the influence between profitability and capital structure on firm value, it is indicated that this is the research gap in this study. This study examines the analysis of the effect of profitability and capital structure on firm value by taking research samples at state-owned banks listed on the Indonesia Stock Exchange (IDX). Based on the explanation above, the purpose of this study is to analyze the relationship and influence of profitability and capital structure variables on firm value.

Based on theoretical studies and empirical studies related to the relationship between variables, the research concept can be explained through the following conceptual framework:

Figure 1. Conceptual Framework

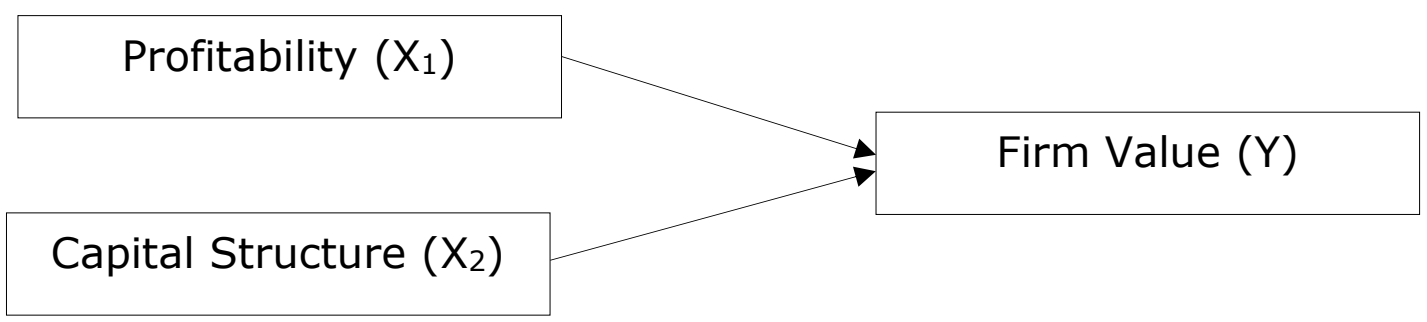

The profitability of the company is one of the factors in the market assessment of the company. Based on signaling theory, profitability is a way for companies to provide information related to profits that have been made 
by management in order to realize the wishes of investors. Musabbihan and Purnawati (2018) found that profitability has a positive effect on firm value. The large profitability generated by the company can be used by investors in making decisions to invest by purchasing shares of issuers. This is done because the increased net profit is able to affect the interest of investors to invest and only in the company which will have an impact on increasing the value of the company. The research of Musabbihan and Purnawati (2018) is strengthened by the research of Wijaya and Sedana (2015), Chen and Chen (2011) So that the first hypothesis in this study is:

H1: Profitability has an effect on firm value.

Capital structure is the proportion of permanent long-term financing consisting of preferred stock, common stock equity and debt. If the company uses long-term debt to finance its assets, the value of the company can be increased. This is in line with the trade off theory where companies can take advantage of debt as long as there are benefits (savings in taxes and other costs compared to paying interest). In line with this, signaling theory also explains that if the company's internal funds are used to finance its business, investors will see it as a positive signal. Hautes and Muslichah (2019) stated that capital structure has a positive and significant influence on firm value. So based on these thoughts, the hypotheses proposed in this study are:

$\mathrm{H} 2$ : Capital structure has an effect on firm value.

\section{METHOD}

This research is an associative research because it explains the relationships between existing variables. The population of this study is state-owned banking companies listed on the Indonesia Stock Exchange in the period 2014 to 2018. The population is taken based on state-owned companies engaged in the banking industry. This study uses a data pooling technique (census) by examining all elements of the population so that the entire population of state-owned banks is studied by 4 (four) companies. The source of the research data was obtained by taking data from the company's performance report on the official website of the Indonesia Stock Exchange (IDX) at www.idx.co.id. The object used in this study is the value of state-owned banking companies on the IDX in 2014-2018. This research is a type of quantitative research using secondary data on profitability, capital structure and firm value in state-owned banking companies in Indonesia. The data collection method that will be used in this study is the secondary data documentation method, namely the financial statements of state-owned banking companies listed on the Indonesia Stock Exchange. The analysis technique in this study uses multiple regression with SPSS 23.0 analysis tool.

This study uses two types of variables, namely endogenous variables (firm value) and exogenous variables (profitability and capital structure). 
Firm value can be measured by Earning Per Share (EPS). EPS is a ratio that shows the amount of profit earned from each existing share. The following formula is used to calculate EPS according to Kasmir (2012:207):

$\mathrm{EPS}=\frac{\text { Laba Bersih }}{\text { Jumlah Saham Beredar }} \times 100 \%$

(1)

Capital structure is measured by debt to asset ratio (DAR). According to Harijito (2014), explaining that DAR is the ability to measure company assets financed by company debt at state-owned banking companies. The unit of measurement for DAR is expressed in percent. According to Wiagustini (2014: 93) Debt to Asset Ratio can be calculated using the following formula:

DAR $=\frac{\text { Jumlah Utang }}{\text { Total Asset }} \times 100 \%$

(2)

Profitability is measured by return on assets (ROA) to measure the ability of the company itself to generate profits from the total assets used. Return on assets is calculated using the ratio between net income after tax and total assets. The ROA measurement scale according to Kasmir (2016) is formulated as follows:

ROA $=\frac{\text { Laba Bersih }}{\text { Total Aktiva }} \times 100 \%$

(3)

This research has an influence with multiple regression analysis techniques. The research hypothesis equation model is as follows:

$\mathrm{Y}=\mathrm{a}+\mathrm{bX} 1+\mathrm{bX} 2+$

Where:

$\mathrm{Y}=$ Firm Value

$\mathrm{X} 1$ = Profitability

X2 = Capital Structure

$\mathrm{e}=$ Error

\section{RESULTS AND DISCUSSION Normality Test}

\begin{tabular}{|c|c|c|c|c|}
\hline & $\begin{array}{r}\text { Nor } \\
\text { Sample }\end{array}$ & $\begin{array}{l}\text { Result } \\
\text { Dv-Smirr }\end{array}$ & Test & \\
\hline & & ROA & DAR & EPS \\
\hline $\mathrm{N}$ & & 20 & 20 & 20 \\
\hline Normal Parameters ${ }^{a, b}$ & Mean & 1.8815 & .8385 & 547.9200 \\
\hline
\end{tabular}


Nengah Sukendri \& Ni Putu Ari Aryawati: Firm Value Performance: Proftability.

\begin{tabular}{l|l|r|r|r|}
\hline & Std. Deviation & .69167 & .04568 & 315.24117 \\
\hline \multirow{2}{*}{ Most Extreme Differences } & Absolute & .131 & .157 & .147 \\
\cline { 2 - 5 } & Positive & .131 & .157 & .147 \\
\cline { 2 - 5 } & Negative & -.103 & -.091 & -.093 \\
\hline Test Statistic & & .131 & .157 & .147 \\
\hline Asymp. Sig. (2-tailed) & & $.200^{c, d}$ & $.200^{c, d}$ & $.200^{c, d}$ \\
\hline
\end{tabular}

The normality test was conducted to determine whether the regression model had a residual value that was normally distributed. In this study using the Kolmogrof Smirnov test. Based on table 1 explains that the value of Kolmogrov Smirnov's ROA is 0.131 with a significance level of 0.200 ; Kolmogrov Smirnov DAR value is 0.157 with a significance level of 0.200 ; and the Kolmogrov Smirnov EPS value of 0.147 with a significance level of 0.200 . This shows that the research variables for ROA, DAR and EPS are normally distributed because the significance level is more than 0.05 .

\section{Multicollinearity Test}

Table 2

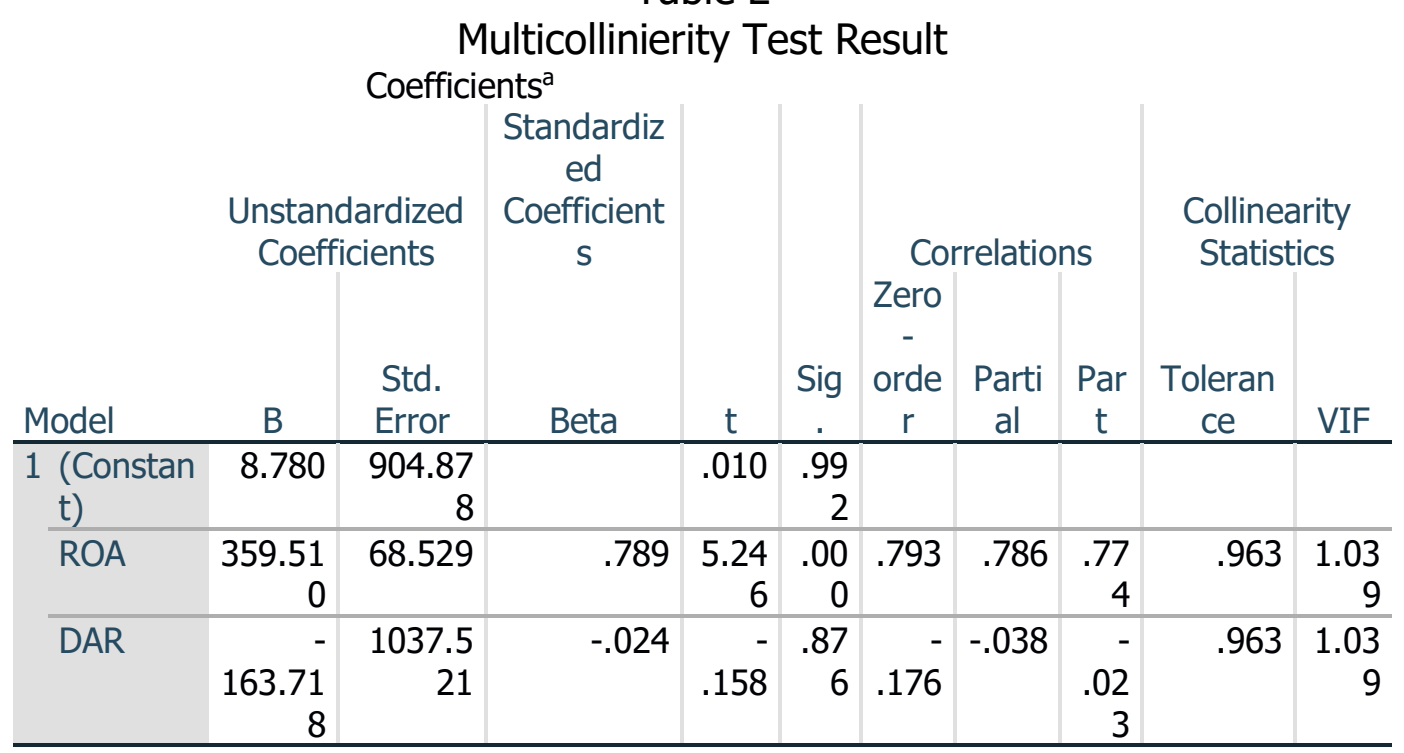

The multicollinearity test is to see whether or not there is a high correlation between the independent variables in a multiple linear regression model. A good regression model, there is no correlation between the independent variables. There is no symptom of multicollinearity if there is no independent variable that has a Tolerance value of less than 0.1 or none has a Variance Inflation Factor (VIF) value of more than 10. Table 2 explains that all known independent variables have a tolerance value greater than 0.1 and VIF is less than 10 , so this study is free from multicollinearity. 


\section{$J A A$}

Vol. 6, No. 1, Oktober 2021

\section{Autocorrelation Test}

\begin{tabular}{|c|c|c|c|c|c|c|c|c|c|c|}
\hline \multirow[b]{3}{*}{$\begin{array}{l}\text { Mod } \\
\text { el }\end{array}$} & \multicolumn{10}{|c|}{$\begin{array}{c}\text { Tabel } 3 \\
\text { Autocorrelation Test Result } \\
\text { Model Summaryb }\end{array}$} \\
\hline & & & & & & Change & Stati & stics & & \\
\hline & $\mathrm{R}$ & $\begin{array}{c}\mathrm{R} \\
\text { Squar } \\
\mathrm{e}\end{array}$ & $\begin{array}{c}\text { Adjuste } \\
\text { d R } \\
\text { Square }\end{array}$ & $\begin{array}{l}\text { Std. } \\
\text { Error of } \\
\text { the } \\
\text { Estimate }\end{array}$ & $\begin{array}{l}\text { Squar } \\
\text { e } \\
\text { Chang } \\
\text { e }\end{array}$ & $\begin{array}{c}\text { F } \\
\text { Chang } \\
\text { e }\end{array}$ & $\begin{array}{c}\mathrm{df} \\
1 \\
\end{array}$ & $\begin{array}{c}\mathrm{df} \\
2 \\
\end{array}$ & $\begin{array}{c}\text { Sig. F } \\
\text { Chang } \\
\text { e }\end{array}$ & $\begin{array}{c}\text { Durbin } \\
- \\
\text { Watso } \\
n\end{array}$ \\
\hline 1 & $\begin{array}{r}.794 \\
a\end{array}$ & .630 & .586 & $\begin{array}{r}202.7241 \\
4\end{array}$ & .630 & $\begin{array}{r}14.47 \\
2\end{array}$ & 2 & 17 & .000 & 1.727 \\
\hline
\end{tabular}

The autocorrelation test aims to test whether in linear regression there is a correlation between the confounding error in period $t$ and the confounding error in period $\mathrm{t}-1$ (previous). A good regression model is if there is no autocorrelation symptom. There is no autocorrelation if the Durbin Watson score is between -2 to +2 . Based on table 3 , the Durbin Watson value is 1.727 , so it can be stated that there is no autocorrelation.

\section{Heteroscedasticity Test}

Tabel 4

Heteroscedasticity Test Result

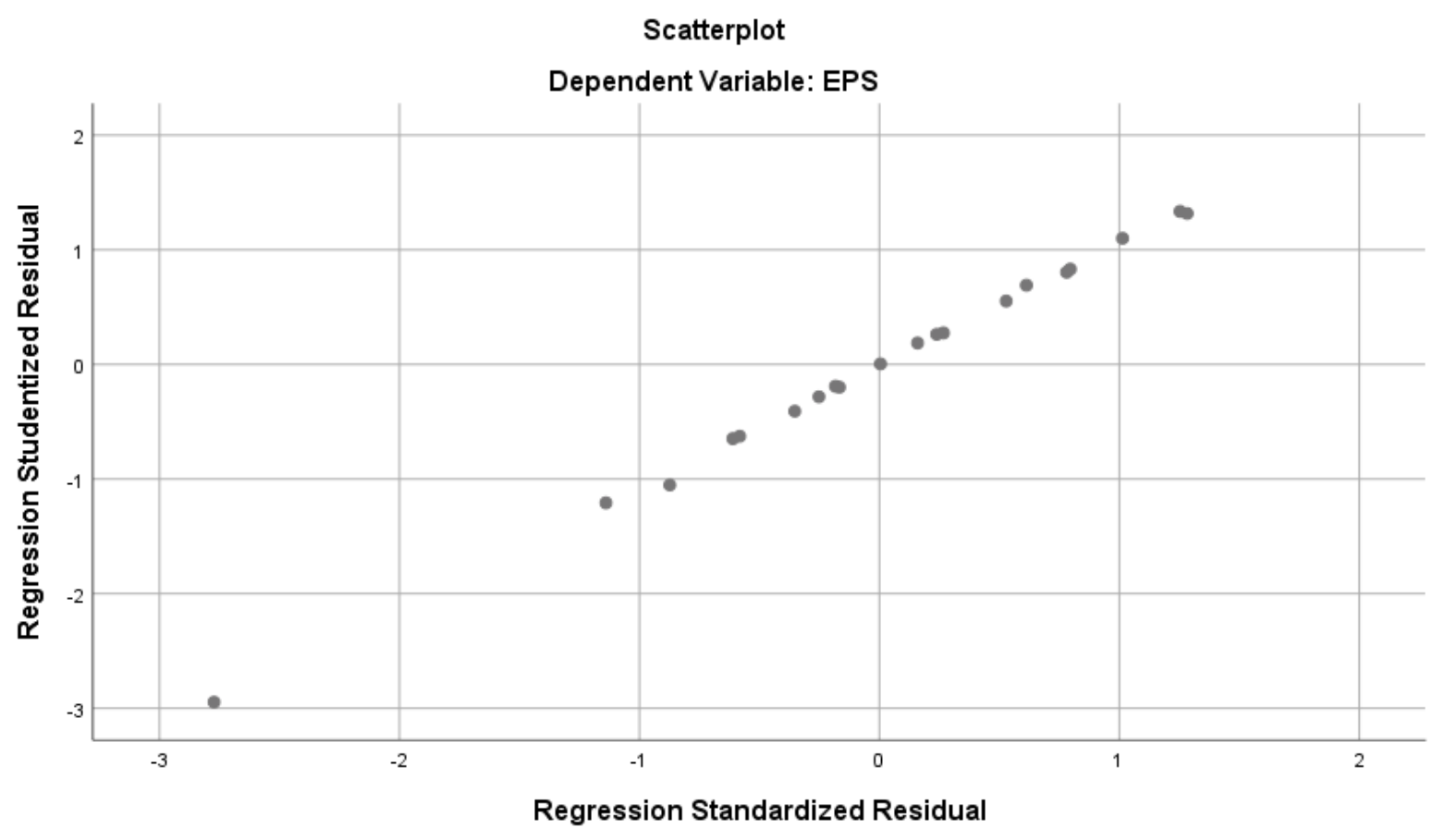

Heteroscedasticity test aims to see whether there is a certain pattern on the scatterplot graph, in this study using a graph plot approach. Table 4 shows 
that the data points are scattered and do not form a certain pattern so that it is said that there is no heteroscedasticity and can be used for research.

Multiple Linear Regression

Table 5

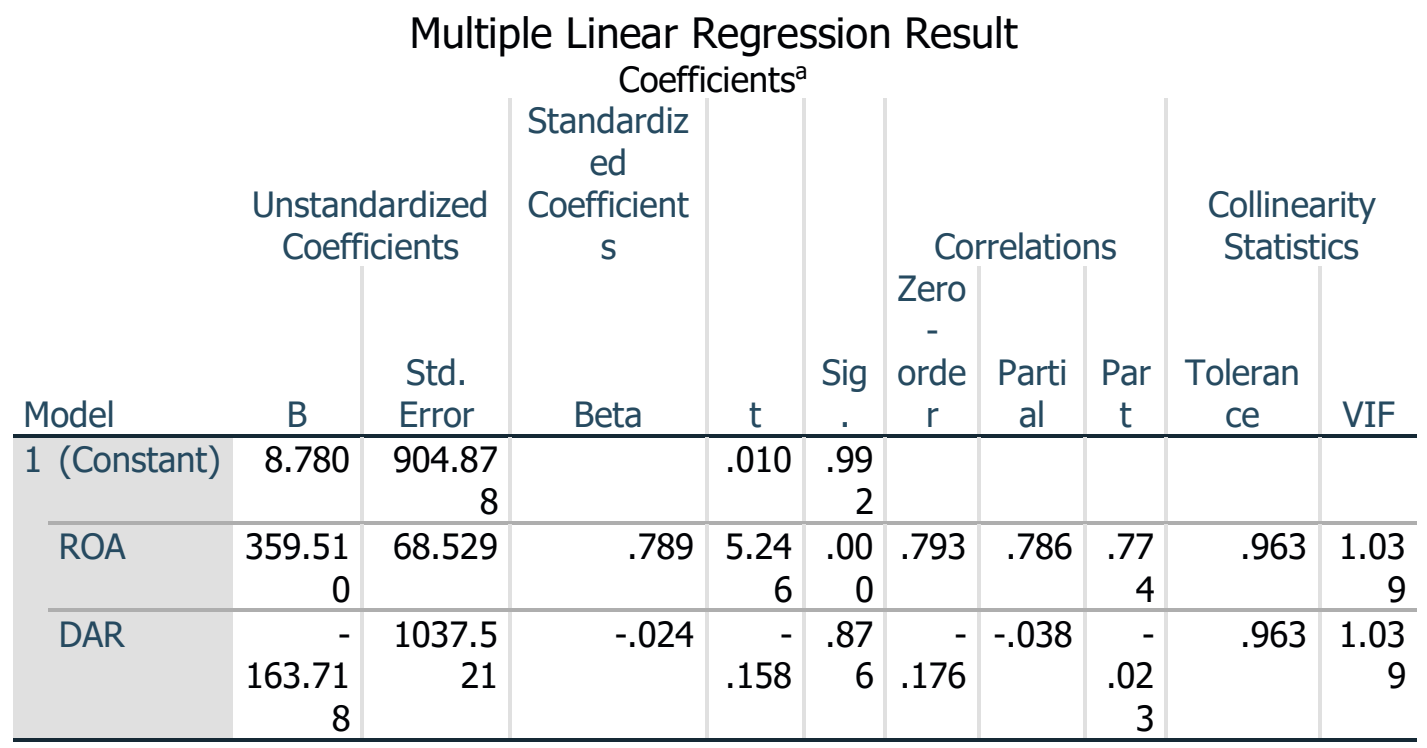

Multiple regression analysis in this study aims to determine whether there is an effect of profitability (Return on Assets), Capital Structure (Debt to Asset Ratio) on firm value (Earning Per Share).

In table 5, the multiple linear regression model is obtained as follows:

EPS $=8.78+359.510$ ROA -163.718 DAR

Based on the multiple regression model above, it can be implemented as follows:

1. The constant value shows a value of 8.78 , explaining that if ROA and DAR are zero, the firm value is 8.78 .

2. The return on Assets coefficient value is positive, namely 359.510 , this indicates a unidirectional change, if the Return On Asset variable has increased by one unit, the firm value will also increase by 359.510 units and vice versa, assuming the other independent variables are constant. The significance value of the ROA variable is stated at 0.000 , which is smaller than 0.05, so Return on Assets has a significant effect on firm value.

3. The coefficient value of the Debt to Asset Ratio is negative, namely 163.718, this indicates a change in the opposite direction, if the Debt to Asset Ratio variable has increased by one unit, the firm value will decrease by -163.718 units and vice versa, assuming the independent variables are other constant. The significance value of the DAR variable is stated at 0.876, which is greater than 0.05, so this Debt to Asset Ratio has no significant effect on firm value. 


\section{$D A$}

Vol. 6, No. 1, Oktober 2021

\section{The Effect of Profitability on Firm Value}

Based on the results of the study, it is known that the significance value of the Return on Assets variable is less than 0.05 , this indicates that Return on Assets has an effect on firm value. The results of this study mean that it is in accordance with the proposed hypothesis that profitability has an effect on firm value. The results of this study are also in line with the results of research by Musabbihan and Purnawati (2018), research by Wijaya and Sedana (2015), Chen and Chen (2011).

The profitability ratio proxied by Return On Assets is a ratio used to measure the company's ability to use its assets. The increasing value of ROA will also increase the value of the company in this case is proxied by the value of Earning Per Share. The existence of information that an increase in the value of a company's ROA will give a positive signal to investors. In accordance with the signal theory that an action taken by a company gives clues or signals to investors about how management views the company's prospects. In this case, the information on the ROA value of a company can make a signal for investors in the decision-making process in making their investments. Therefore, Return on Assets is very important because it reflects the value of the company and is able to influence investors' perceptions of the company.

\section{Effect of Capital Structure on firm value}

Based on the results of the study, it is known that the significance value of the Debt to Asset Ratio variable is greater than 0.05 , this indicates that the Debt to Asset Ratio has no significant effect on firm value. The results of this study mean that it is not in accordance with the proposed hypothesis so that the resulting capital structure does not have a significant effect on firm value.

The capital structure ratio proxied by the Debt to Asset Ratio or Debt Ratio is a debt ratio which is to measure the ability of the company's assets to be financed with debt. This shows that the company in financing with debt has no significant effect on firm value. Ideally, if the company uses long-term debt to finance its assets, the value of the company can be increased, but according to the trade off theory, banking companies, in this case SOEs, can take advantage of debt as long as there are benefits. With the results shown that there is no significant effect, it states that the use of debt in the company's assets is not effective, and is not able to increase the value of the company as proxied by Earning Per Share. This means that the debt in the SOE banking industry has reached its peak or optimum point. This is reinforced by the fact that in the banking industry the largest capital comes from third parties, so that the Bank is expected to be able to perform the intermediation function. 
Therefore, the use of debt on the assets of state-owned banking companies has a limit or peak point that can provide effective benefits to the company. In this case, the use of debt in the company's assets is not able to increase the value of the company. Meanwhile, according to signaling theory, it also explains that if the company's internal funds are used to finance its business, investors will see it as a positive signal, so that in this study the capital structure proxied by the Debt to Asset Ratio variable cannot be used to reflect a positive signal of firm value.

\section{Conclusion}

\section{CONCLUSION}

Return on Assets reflects the value of the company and is able to influence investors' perceptions of the company. Information on the ROA value of a company can be a positive signal for investors in the decision-making process in making their investments. Meanwhile, the Debt to Asset Ratio variable cannot be used to reflect a positive signal of firm value. This means that the debt in the state-owned banking industry has reached its peak or optimum point and in fact the largest capital of state-owned banking companies comes from third party sources.

Based on the results and discussion, it can be concluded that the profitability of state-owned banking companies as proxied by Return On Assets has a significant effect on firm value and capital structure proxied by Debt to Asset Ratio has no significant effect on firm value.

\section{Limitations}

The limitations in this study are limited in using the variables measured by proxying Return on Assets and Debt to Asset Ratio as independent variables and Earning Per Share as dependent variables. In addition, there are limitations in the use of the research time period, namely 2014 to 2018, specifically examining profitability and capital structure on firm value at state-owned banks in Indonesia. From the limitations of this study, it can be a recommendation for further research to conduct studies and research using other relevant variables and also conduct studies on the development of the next period.

\section{REFERENCES}

Brigham, Eugene F. And J. F. Houston. 2010. Fundamentals of Financial Management. Edition 11. Jakarta: Salemba Empat.

Chen, D., Wang, R., Tjiu, W. W., \& Liu, T. (2011). High performance polyimide composite films prepared by homogeneity reinforcement of electrospun nanofibers. Composites Science and Technology, 71(13), 1556-1562. 


\section{$J A A$}

Vol. 6, No. 1, Oktober 2021

Dewi, D. A. I. Y. M., \& Sudiartha, G. M. (2017). Effect of Profitability, Company Size, and Asset Growth on Capital Structure and Firm Value (Doctoral dissertation, Udayana University).

Harijito, Agus. (2014). Financial management. Yogyakarta: Econesia.

Hauteas, O.S. (2019). The Effect of Profitability and Dividend Policy on Firm Value With Capital Structure as a Mediation Variable. Journal of Management and Finance, 8(2), 177-192.

Munawaroh, A., \& Priyadi, M. P. (2014). The effect of profitability on firm value with corporate social responsibility as a moderating variable. Journal of Accounting Science \& Research, 3(4), 1-17.

Musabbihan, N. A., \& Purnawati, N. K. (2018). The Effect of Profitability and Dividend Policy on Firm Value With Capital Structure as Mediating (Doctoral Dissertation, Udayana University).

Priyatama, T., \& Pratini, E. (2021). The Effect of Capital Structure, Profitability, Liquidity, and Firm Size on Firm Value (Empirical Study on Infrastructure, Utilities, and Transportation Companies Listed on the Indonesia Stock Exchange for the 2015-2018 Period). Exist: Scientific Journal of Economics and Business, 12(1), 100-106.

Putra, I. W. J., \& Wiagustini, N. L. P. (2014). Effect of Leverage and Profitability on Dividend Policy and Company Value (Doctoral dissertation, Udayana University).

Riaz, M., \& Qasim, M. (2016). Journal of ISOSS 2016 Vol. 2 (1), 97-101 Islamic Microfinance Institution: The Capital Structure, Growth, Performance And Value Of The Firm In Pakistan. Journal of ISOSS, 2(1), 97-101.

Wicaksono, R., \& Mispiyanti, M. (2020). Analysis of the Effect of Profitability and Dividend Policy on Firm Value with Capital Structure as a Mediation Variable. Owner: Research and Journal of Accounting, 4(2), 396-411.

Wijaya, B. I., \& Sedana, I. P. (2015). The effect of profitability on firm value (dividend policy and investment opportunities as mediating variables). E-Journal of Management, 4(12). 